\title{
Studies on Seed Quality Parameters in Different Genotypes of Vegetable Pea (Pisum sativum L.) in Mid Hills of Uttarakhand, India
}

\author{
Abhishek Panwar ${ }^{1}$, A.C. Mishra ${ }^{2}$, Shivangi Negi ${ }^{1}$, Sanjay Negi $^{3}$ and Paramjeet Sajwan ${ }^{3}$ \\ ${ }^{1}$ Department of Seed Science and Technology, ${ }^{2}$ Department of Vegetable Science, \\ ${ }^{3}$ Department of fruit Science, VCSG Uttarakhand University of Horticulture and Forestry, \\ Bharsar, Uttarakhand, India \\ *Corresponding author
}

Keywords

Genotypes, Germination, Vigour index, Correlation

Article Info

Accepted:

15 December 2019 Available Online: 20 January 2020
The present investigation was carried out during the Rabi season in Pisumsativumin 2014-15 at Seed Science and Technology Laborotry, Department of Seed Science and Technology, VCSG UUHF, Ranichauri Campus, TehriGarhwal, Uttarakhand. It comprised 16 genotypes of vegetable pea (Pisumsativum L.) including released commercial cultivars and elite lines developed from different Institutes of India. The seed samples of each genotype were subjected to laboratory testing in Complete Randomised Design for 100 seed weight, first count, standard germination, root length, shoot length, seedling length, seedling fresh weight, seedling dry weight, vigour index-I and vigour index-IIwith view to find out relationship of seed viability and seedling vigour parameters with field performance of the genotypes. The genotype Pea-1001 registered maximum value for first count $(73.66 \%)$, standard germination $(92.33 \%)$, seedling fresh weight $(4.07 \mathrm{~g})$, seedling dry weight $(0.92 \mathrm{~g})$, vigour index-II (87.09).Correlation studies showed positively and significantly correlation with standard germination (0.807), seed vigour index-II (0.654), seedling fresh weight (0.60) and seedling dry weight (0.59). Highly significant and positive correlation was observed with seed vigour index-II (0.392) and seedling dry weight (0.39). It is evident that prior estimation of standard germination, seedling dry weight and seedling vigour index-II of the seed lot in any genotype could be used to predict the yield potentiality of that genotype in open field conditions and the genotypes with higher values for these seed traits could be assumed to give higher pod and seed yield. 


\section{Introduction}

Pea (Pisum sativum L.) one of the most important annual legume crop of India, belongs to the family Leguminousae (Fabaceae). There are two sub species, namely Pisumsativum var. arvense known as field pea, having colored flowers and Pisum sativum var. sativum, the white flowered garden pea, is largely confined to cooler temperate zone between the Tropic of Cancer and Mediterranean region. Being a cool season crop, it is most extensively grown in the temperate region throughout the world. Pea can be grown successfully during midsummer and early fall in those areas having relatively low temperature and good rainfall or where irrigation is practiced. For very early crop, sandy loam is preferred, for higher yield where earliness is not a factor, a well-drained clay loam or silt loam is preferred (Duke, 1981).Being a cool season crop, it is most extensively grown in the temperate regions throughout the world. In tropics and subtropics, its cultivation is restricted to higher altitude and winter season. In India, annual production of vegetables is 162.187 million metric tonnes from the area 9.205 million hectares. Pea contributes 5452 million metric tonnes production from the area of 546 million hectares in the country. In Uttarakhand, pea is grown on an area of 11.84 million hectares with an annual production of 83.03 million metric tonnes (Anon, 2018). The edible green pod contains 7.2 percent protein, 15.9 percent carbohydrate and 0.1 percent fat in $100 \mathrm{~g}$ of fresh pod. It is also an excellent source of minerals such as potassium $(170.0 \mathrm{mg})$, phosphorus (139.0 mg), calcium $(20.0 \mathrm{mg})$, magnesium $(6.0 \mathrm{mg})$ and iron $(1.5 \mathrm{mg})$ per $100 \mathrm{~g}$ of green edible seed. The mature grain may be used as whole or prepared in various ways for human consumption. Pea has adequate amount of carotene $(83 \mu \mathrm{g})$, vitamin C $(9 \mathrm{mg})$, thiamine $(0.25 \mathrm{mg})$ and riboflavin $(0.01 \mathrm{mg})$ per $100 \mathrm{~g}$ of edible portion. Beside, pea contains all essential indispensable amino acids required in human foods (Choudhary, 2003). High quality seed is essential and desirable to ensure good crop establishment. For many field crops, one of the main problems observed is poor crop stand establishment of which is influenced by seed quality, adverse climatic condition, poor field management etc. (Maiti et al., 2002). Seed germination and vigour are main physiological quality attributes. Since the standard germination test has proved to be an important tool for measuring seed lot performance under adverse field conditions much effort have been given to develop a test or group of test that can determine seed vigour accurately. The present investigation was carried out with the objective of partitioning the observed variability in seed vigour traits of vegetable pea germplasm in lab condition.

\section{Materials and Methods}

The present investigation was carried out during the Rabi season of 2014-15 at Seed Science and Technology Laboratory, Department of Seed Science and Technology, Veer Chandra Singh Garhwali Uttarakhand University of Horticulture and Forestry, Ranichauri Campus, TehriGarhwal, Uttarakhand is located on north facing between $30^{\circ} 18^{\prime} \mathrm{N}$ latitude and $78^{\circ} 24^{\prime} \mathrm{E}$ longitude at an elevation of 2000-2200 m above mean sea level. Ranichauri campus experiences humid and temperate type of climate with chilled winters. The mean monthly maximum and minimum temperature during pea crop period (Dec to May) varies between 27.2 to $17.4^{\circ} \mathrm{C}$ and $17.6^{\circ} \mathrm{C}$ to $6.5^{\circ} \mathrm{C}$, respectively. The experimental material for the present investigation comprised of 16 genotypes obtained from various Agricultural Universities and Institutes of the country. The experiment was laid out in Complete Randomized Block Design with three replications.Observations were recorded for 
laboratory conditions were first count (\%), standard germination $(\%)$, root length $(\mathrm{cm})$, shoot length $(\mathrm{cm})$, seedling length $(\mathrm{cm})$, seedling fresh weight $(\mathrm{g})$, seedling dry weight (g), vigour Index-I, vigour Index-II and 100 seed weight $(\mathrm{g})$.

\section{Results and Discussion}

Mean performance of pea (Pisum sativum L.) genotypes for seed quality parameters under laboratory conditions

The analyzed data on 100 seed weight presented in Table1. It ranged from $16.30 \mathrm{~g}$ to $26.03 \mathrm{~g}$ with maximum in VL-7 $(26.03 \mathrm{~g})$ followed by VRP-7 (25.03 g) with statistically at par values. The minimum 100 seed weight was recorded in AP-2 $(16.30 \mathrm{~g})$. The mean value of population was $21.40 \mathrm{~g}$. The characters like 100 seed weight are related to seed boldness primarily related to seed vigour in vegetable pea. The bold and bulky seeded genotypes might be presumed to have better potentiality of germination and further growth and development. There are meagre works reported on seed weight of vegetable pea. However, Singh and Singh (2006); Kumar (2007) and Shukla et al., (2010) have reported a wide range of variability in 100 seed weight across the genotypes of pea. Similarly, Shukla et al., (2009) have also realized significant variability in 100 seed weight of horse gram genotypes ranging from $2.65 \mathrm{~g}$ in PRH 04 to $3.33 \mathrm{~g}$ in PRH 09.

\section{First count (\%)}

The first count is percentage of germination of seeds after 5 days of sowing. The different genotypes exhibited significant variation in first count which ranged from $60.0 \%$ to $73.66 \%$. Maximum value of first count was observed in Pea-1001 (73.66\%) followed by statistically at par values in Arkel, PSM-3 (70.0\%), PM-2 (69.66\%) and AP-2 (69.33\%).
The minimum first count was found in VL-7 $(60.0 \%)$. The mean value of the population was $68.13 \%$ (Table1).

First count is an indicator of earliness in germination of the genotypes. Early germinating genotypes may likely to produce early yield in vegetable pea which is an concern of pea growers in hilly areas. Variability in first count has also been reported by Kumar (2007) from $16.67 \%$ to 70.0\%; Pant (2008) from 5.33\% to $16.66 \%$; and Prasad (2009) from $0.0 \%$ to $54.04 \%$ across the genotypes in vegetable pea.

\section{Standard germination $(\%)$}

Germination is a complex critical character under marginal environmental conditions. It is one of the important criteria for determining the physiological aspect of seed and gives an idea about the ability of seed to produce normal and healthy seedling under the field conditions. During seed germination, various stored substrates are reactivated, repaired, transformed into new building materials necessary for the initial growth of embryo, its subsequent growth and seedling establishment in its natural habitat Koller and Hadas (1982). There was significant difference among the genotypes for standard germination. However, the range of maximum to minimum standard germination across the genotypes was narrow $(82.33 \%$ to $92.33 \%)$. Maximum value for this trait was observed in Pea-1001 (92.33 \%) followed by statistically at par values in P-89 (90.66\%), Pea-801 (90.33\%), PSM-4 (90.33\%), Pea-901 (90.0\%), PC-531 (88.33\%), PSM-3 (88.33\%), Arkel (88.00\%) and PM-2 $(88.00 \%)$. The minimum standard germination was found in JM-1 $(82.33 \%)$. The Population mean was $87.5 \%$.

Comparable range of standard germination have also been observed by Kumar (2007) from $61.67 \%$ to $99.33 \%$; Pant (2008) from 
$76.66 \%$ to $99.00 \%$ and Prasad (2009) from $71.06 \%$ to $92.80 \%$ in vegetable pea.

\section{Root length (cm)}

Root length of seedlings implies genetic potentiality of seedling to establish itself in resource (soil moisture) rich delphic atmosphere. Higher seedling root length, there will be more ability of seedlings (further plants) to survive in moisture stress conditions. The analyzed data on root length indicated significant difference among pea genotypes for root ranging from $7.75 \mathrm{~cm}$ to $14.85 \mathrm{~cm}$. Maximum value was registered in VRP-7 $(14.85 \mathrm{~cm})$ followed by Pea-801 $(14.48 \mathrm{~cm})$ which were statistically at par. Some other genotypes with higher root length were Pea-902 (12.66 cm), Pea-1001 (12.20 $\mathrm{cm})$, VL-7 (12.07 cm), PSM-4 (11.48 cm) and P-89 $(11.15 \mathrm{~cm})$. The minimum root length was found in PSM-3 $(7.75 \mathrm{~cm})$. The population mean was $10.85 \mathrm{~cm}$.

Although, root length is a character not directly related to pod yield but it has importance in stress tolerance. The genotypes with higher root length can better withstand water stress conditions in rainfed hills. In this way, root length has indirect effect on plant growth and pod yield of garden pea. Variability in root length of garden pea genotypes corresponding to present investigation has also been realized by Kumar (2007) from $11.0 \mathrm{~cm}$ to $26.33 \mathrm{~cm}$; Pant (2008) from $11.1 \mathrm{~cm}$ to $19.46 \mathrm{~cm}$ and Prasad (2009) from $6.94 \mathrm{~cm}$ to $18.34 \mathrm{~cm}$ in vegetable pea.

\section{Shoot length (cm)}

The genotypes exhibited wide range of variability for shoot length ranging from 2.56 $\mathrm{cm}$ to $7.96 \mathrm{~cm}$. Significantly higher value of shoot length was recorded in Pea-801 (7.96 $\mathrm{cm})$ followed by Pea-902 $(6.98 \mathrm{~cm})$, AP-2 $(5.77 \mathrm{~cm})$ and $\mathrm{AP}-3(5.37 \mathrm{~cm})$. The minimum root length was found in PM-2 $(2.56 \mathrm{~cm})$. The mean value of the population was $4.76 \mathrm{~cm}$.

Shoot length is an indicator of genotypes to have ability of earliness in germination. More shoot length implies earliness of the genotype in respect of germination and probably also of flowering and fruiting. Variability in shoot length of garden pea genotypes has also been reported by Kumar (2007) from $8.0 \mathrm{~cm}$ to $19.00 \mathrm{~cm}$; Pant (2008) from $5.66 \mathrm{~cm}$ to 9.26 $\mathrm{cm}$ and Prasad (2009) from $4.20 \mathrm{~cm}$ to 5.60 $\mathrm{cm}$.

\section{Seedling length $(\mathrm{cm})$}

The overall seedling length is function of root and shoots length. It indicates growth rate and growth habit of the genotypes. Seedling length has direct correlation with seed vigour during the germination process, the seed which produce taller seedling are considered to be more vigorous than those which produce shorter seedling.

The analyzed data for seedling length indicated that there was significant difference among the genotypes for this trait ranging from $10.56 \mathrm{~cm}$ to $22.43 \mathrm{~cm}$. significantly higher value of seedling length was noted in Pea-801 $(22.43 \mathrm{~cm})$. The other genotypes with comparatively higher seedling length were Pea-902 $(19.65 \mathrm{~cm})$ and VRP-7 $(19.30 \mathrm{~cm})$ whereas, minimum value was observed in PM-2 $(10.56 \mathrm{~cm})$. The general mean of the population was $15.50 \mathrm{~cm}$.

Increasing trend of seedling length in the genotypes was accompanied with good germination capacity of the seeds. Variable results on variability in the seedling length of pea genotypes have also been reported by Kumar (2007) from $23.33 \mathrm{~cm}$ to $42.00 \mathrm{~cm}$; Pant (2008) from $18.23 \mathrm{~cm}$ to $28.96 \mathrm{~cm}$ and Prasad (2009) from $11.15 \mathrm{~cm}$ to $15.58 \mathrm{~cm}$. 


\section{Seedling fresh weight $(\mathrm{g})$}

The analyzed data on seedling fresh weight as given in Table 1 indicated that all sixteen genotypes included in present investigation had significant variation for this trait. It ranged from $2.36 \mathrm{~g}$ to $4.07 \mathrm{~g}$. Maximum value was noted in Pea-1001 (4.07 g) followed by Pea801 (3.83 g) which were statistically at par. The other genotypes with higher values of seedling fresh weight were Arkel $(3.63 \mathrm{~g}$ ), PSM-4 (3.57 g), Pea-901 (3.51 g), Pea-902 $(3.50 \mathrm{~g})$ and PC531 (3.43 g). The minimum seedling fresh weight was found in JM-1 (2.36 g). The population mean was $3.21 \mathrm{~g}$. Comparable variability in seedling fresh weight of garden pea genotypes have also been reported by Kumar (2007) $4.34 \mathrm{~g}$ to 8.51 $\mathrm{g}$; Pant (2008) from $2.86 \mathrm{~g}$ to $4.90 \mathrm{~g}$ and Prasad (2009) from $3.65 \mathrm{~g}$ to $5.11 \mathrm{~g}$.

\section{Seedling dry weight (g)}

Seedling dry weight is a measure of total accumulation of dry matter in the seedlings. Since, the dry matter is estimated in laboratory condition at very initial stage of life cycle when photosynthetic system has not been activated. Therefore the level of dry matter content in seedlings at this stage is directly related to food reserves of the seeds. Seedling dry weight is an important attribute which determines vigour of the seedling. Bolder seeds produce healthy seedling and have more dry weight than that of the small seeds. Plants grown in the favourable conditions produce healthy and bold seeds which in turn resulted in higher dry weight. Seedling dry weight is an important character as it is directly correlated to seed vigour. Seed lot having higher seedling dry weight considered to have higher vigour (Raturi, 2013).The analysed data on seedling dry weight as depicted in Table1 indicate a wide range of variability from $0.52 \mathrm{~g}$ to $0.94 \mathrm{~g}$. Maximum value of this parameter was recorded in Pea-1001 (0.94 g) followed by statistically at par values in PSM$4(0.92 \mathrm{~g})$ and PC-531 (0.87 g). The second group of genotypes with higher seedling dry weight was P-89 (0.86 g), Pea-901 (0.84 g), Pea-801 (0.82 g) and VL-7 (0.79 g). The minimum seedling dry weight was found in PM-2 $(0.52 \mathrm{~g})$. The population mean was 0.73 g. A wide range of variability in seedling dry weight of pea genotypes have also been reported by Kumar (2007) from $0.42 \mathrm{~g}$ to 1.13 $\mathrm{g}$; Pant (2008) from $0.45 \mathrm{~g}$ to $0.95 \mathrm{~g}$ and Prasad (2009) from $0.72 \mathrm{~g}$ to $1.06 \mathrm{~g}$.

\section{Vigour index-I}

Seedling vigour index-I is related to the size factor of seedlings. Vigour is a qualitative term encompassing the sum of those properties of the seed which determine the potential level of activity and performance of seed or seed lot during germination and seedling emergence (Perry, 1984).All the sixteen genotypes included in this experiment, exhibited significant variation in vigour indexI ranging from 928.50 to 2027.08 (Table1). Maximum and significantly higher vigour index-I was worked out in Pea-801 (2027.08). The minimum vigour index-I was found in PM-2 (928.50). The mean value of the population was 1358.20 . A comparable range seedling vigour index-I has also been reported by Pant (2008) from 1446 to 2809 and Prasad (2009) from 754.21 to 1143.41. However, Kumar (2007) reported quite high range of variability in vigour index-I from 143.0 to 4142.67 across the garden pea genotypes.

\section{Vigour index-II}

The seedling vigour index-II is a parameter related to weight factor of the seedlings. Seed vigour index-mass is another important parameter which determines the performance of seeds in fields conditions which is attributed to germination and seedling dry weight. There was significant variation in 
seedling vigour index-II across the sixteen genotypes ranging from 45.46 to 87.09 . Maximum vigour index-II was recorded in Pea-1001 (87.09) followed by statistically at par values in PSM-4 (83.08) and P-89 (78.43). The minimum vigour index-II was found in AP-2 (45.46). The mean value of the population was 63.90 (Table1). Significant variability in seedling vigour index-II in garden pea genotypes has also been reported by Kumar (2007) from 31.48 to 113.99; Pant (2008) from 36.96 to 101.30 and Prasad (2009) from 52.99 to 85.50 .

The above results indicated that sixteen genotypes included in present investigation varied significantly for all the seed and seedling viability and vigour parameters studied. The genotype Pea-1001 registered maximum value for first count (73.66\%), standard germination (92.33\%), seedling fresh weight $(4.07 \mathrm{~g})$, seedling dry weight $(0.92 \mathrm{~g})$ and vigour index-II (87.09) whereas, Pea-801 emerged promising for shoot length $(7.96 \mathrm{~cm})$, seedling length $(22.43 \mathrm{~cm})$ and vigour index-I (2027.08). Maximum value for 100 seed weight was noted in VL-7 (26.03 g) whereas; VRP-7 had highest root length $(14.85 \mathrm{~cm})$.

The genotype Pea-1001 registered maximum value for first count $(73.66 \%)$, standard germination $(92.33 \%)$, seedling fresh weight (4.07 g), seedling dry weight $(0.92 \mathrm{~g})$ and vigour index-II (87.09) whereas, Pea-801 emerged promising for shoot length $(7.96 \mathrm{~cm})$, seedling length $(22.43 \mathrm{~cm})$ and vigour index-I (2027.08). Maximum value for 100 seed weight was noted in VL-7 (26.03 g) whereas; VRP-7 had highest root length $(14.85 \mathrm{~cm})$ (Table1). The seed quality parameters as assessed in lab conditions represent overall viability of seeds. These results were comparable with those obtained by earlier workers in pea viz., Pant (2008), Prasad (2009), Pal et al., 2013 and Siddika et al., 2013.
Estimates of correlation coefficients of different characters in vegetable pea genotypes

Correlation coefficients of pod yield and seed yield per plant with seed quality characters: The assessment of seed viability and vigour traits by growing the seed samples of different genotypes in the laboratory condition before sowing in main field and further estimation of performance in field conditions enables to establish relationship between seed quality parameters and field performance. With the help of such relations, the potentiality of seed lot of a genotype could be assumed in advance. The estimates of correlation coefficients among different pairs of characters have been presented in Table 2 .

The results on correlation studies showed that seed yield per plant exhibited highly significant and positive correlation with seed vigour index-II (0.392) and seedling dry weight (0.390) whereas it established positive but non-significant association with standard germination (0.283) and root length (0.180). Pod yield per plant, positive and significant relation of it was found with standard germination (0.807), seed vigour index-II (0.654), seedling fresh weight (0.600) and seedling dry weight (0.597). It appeared from such type of inter-relationships that the genotypes exhibiting high values for standard germination, seed vigour index-II and seedling fresh and dry weight, could be assumed to have high pod as well as seed yield per plant. Corroborating the findings of present investigation, high positive correlation of seed vigour index, seedling dry weight and standard germination with seed yield per plant have also been reported byNatrajan (2002), Jitender et al., (2010) and Ghobary (2010) Kumar (2007), Pant (2008), Prasad (2009) and Shukla et al., 2009 in vegetable pea. 
Table.1 Mean performance of pea (Pisumsativum L.) genotypes for seed quality parameters under laboratory conditions

\begin{tabular}{|c|c|c|c|c|c|c|c|c|c|c|c|}
\hline S. N. & Genotype & $\begin{array}{c}\text { First } \\
\text { count } \\
(\%)\end{array}$ & $\begin{array}{c}\text { Standard } \\
\text { germinatio } \\
\text { n }(\%)\end{array}$ & $\begin{array}{c}\text { Root } \\
\text { length } \\
(\mathrm{cm})\end{array}$ & $\begin{array}{c}\text { Shoot } \\
\text { length } \\
(\mathrm{cm})\end{array}$ & $\begin{array}{l}\text { Seedlin } \\
\text { g length } \\
(\mathrm{cm})\end{array}$ & $\begin{array}{c}\text { Seeding } \\
\text { fresh } \\
\text { weight }(g)\end{array}$ & $\begin{array}{c}\text { Seedling } \\
\text { dry } \\
\text { weight g) }\end{array}$ & $\begin{array}{c}100 \text { seed } \\
\text { weight } \\
(\mathrm{g})\end{array}$ & $\begin{array}{c}\text { Vigour } \\
\text { index- } \\
\text { II }\end{array}$ & $\begin{array}{l}\text { Vigour } \\
\text { index-II }\end{array}$ \\
\hline 1 & AP-2 & 69.33 & 85.66 & 10.16 & 5.77 & 15.93 & 2.93 & 0.53 & 16.30 & 45.46 & 45.46 \\
\hline 2 & PM-2 & 69.66 & 88.00 & 7.99 & 2.56 & 10.56 & 2.69 & 0.52 & 22.16 & 46.28 & 46.28 \\
\hline 3 & Pea-902 & 68.33 & 84.33 & 12.66 & 6.98 & 19.65 & 3.50 & 0.67 & 21.40 & 56.62 & 56.62 \\
\hline 4 & AP-3 & 68.00 & 84.33 & 9.65 & 5.37 & 15.01 & 2.88 & 0.65 & 24.13 & 55.54 & 55.54 \\
\hline 5 & JM-1 & 66.33 & 82.33 & 9.09 & 4.62 & 13.72 & 2.36 & 0.55 & 20.93 & 45.61 & 45.61 \\
\hline 6 & PSM-3 & 70.00 & 88.33 & 7.75 & 3.54 & 11.29 & 3.41 & 0.63 & 18.13 & 55.69 & 55.69 \\
\hline 7 & VRP-7 & 68.33 & 87.66 & 14.85 & 4.45 & 19.30 & 2.81 & 0.67 & 25.03 & 59.35 & 59.35 \\
\hline 8 & PSM-4 & 68.00 & 90.33 & 11.48 & 4.25 & 15.73 & 3.57 & 0.92 & 22.60 & 83.08 & 83.08 \\
\hline 9 & VL-7 & 60.00 & 85.00 & 12.07 & 5.32 & 17.40 & 2.89 & 0.79 & 26.03 & 67.61 & 67.61 \\
\hline 10 & Pea-1001 & 73.66 & 92.33 & 12.20 & 5.73 & 17.93 & 4.07 & 0.94 & 19.03 & 87.09 & 87.09 \\
\hline 11 & CHP-2 & 65.66 & 85.00 & 8.47 & 3.59 & 12.06 & 2.59 & 0.71 & 24.03 & 60.95 & 60.95 \\
\hline 12 & Pea-801 & 67.66 & 90.33 & 14.48 & 7.96 & 22.43 & 3.83 & 0.82 & 22.10 & 74.10 & 74.10 \\
\hline 13 & Arkel & 70.00 & 88.00 & 9.03 & 4.61 & 13.64 & 3.63 & 0.60 & 21.36 & 53.07 & 53.07 \\
\hline 14 & Pea-901 & 65.00 & 90.00 & 10.85 & 3.69 & 14.55 & 3.51 & 0.84 & 22.00 & 75.92 & 75.92 \\
\hline 15 & PC-531 & 68.00 & 88.33 & 9.97 & 3.94 & 13.91 & 3.43 & 0.87 & 19.73 & 77.47 & 77.47 \\
\hline \multirow[t]{4}{*}{16} & P-89 & 68.00 & 90.66 & 11.15 & 3.72 & 14.88 & 3.22 & 0.86 & 17.46 & 78.43 & 78.43 \\
\hline & GM & 68.13 & 87.5 & 10.85 & 4.76 & 15.50 & 3.21 & 0.73 & 21.40 & 63.90 & 63.90 \\
\hline & $\mathrm{CV}(\%)$ & 4.023 & 3.01 & 2.57 & 2.56 & 2.25 & 6.54 & 5.84 & 5.06 & 7.63 & 7.63 \\
\hline & $\begin{array}{c}\text { CD } \\
(0.05)\end{array}$ & 4.55 & 4.39 & 0.46 & 0.20 & 0.58 & 0.35 & 0.07 & 1.80 & 8.13 & 8.13 \\
\hline
\end{tabular}


Table.2 Estimates of correlation coefficients between seed yield and pod yield per plant with seed quality characters in vegetable pea genotypes

\begin{tabular}{|c|c|c|c|c|c|c|c|c|c|c|c|}
\hline Characters & $\begin{array}{c}\text { Standard } \\
\text { germination } \\
(\%)\end{array}$ & $\begin{array}{l}\text { Root } \\
\text { length } \\
(\mathrm{cm})\end{array}$ & $\begin{array}{l}\text { Shoot } \\
\text { length } \\
(\mathrm{cm})\end{array}$ & $\begin{array}{l}\text { Seedling } \\
\text { length } \\
(\mathrm{cm})\end{array}$ & $\begin{array}{l}\text { Seedling } \\
\text { fresh } \\
\text { weight }(g)\end{array}$ & $\begin{array}{l}\text { Seedling } \\
\text { dry } \\
\text { weight (g) }\end{array}$ & $\begin{array}{l}\text { Vigour } \\
\text { Index-I }\end{array}$ & $\begin{array}{c}\text { Vigour } \\
\text { Index- II }\end{array}$ & $\begin{array}{c}100 \\
\text { seed } \\
\text { weight } \\
(\mathrm{g})\end{array}$ & $\begin{array}{c}\text { Seed } \\
\text { yield } \\
\text { per } \\
\text { plant }(\mathrm{g})\end{array}$ & $\begin{array}{l}\text { Pod yield } \\
\text { per plant } \\
\text { (g) }\end{array}$ \\
\hline \multirow{2}{*}{\multicolumn{12}{|c|}{$\begin{array}{c}\text { First count } \\
(\%)\end{array}$}} \\
\hline & & & & & & & & & & & \\
\hline $\begin{array}{c}\text { Standard } \\
\text { germination } \\
(\%)\end{array}$ & & 0.285 & -0.087 & 0.152 & $0.749 * *$ & $0.659 * *$ & 0.302 & $0.742 * *$ & -0.302 & 0.283 & $0.807 * *$ \\
\hline $\begin{array}{l}\text { Root length } \\
\text { (cm) }\end{array}$ & & & $0.642 * *$ & $0.944 * *$ & $0.362 *$ & $0.464 *$ & $0.952 * *$ & $0.456^{*}$ & 0.265 & 0.188 & 0.330 \\
\hline $\begin{array}{l}\text { Shoot length } \\
\text { (cm) }\end{array}$ & & & & $0.859 * *$ & $0.382 *$ & 0.108 & $0.818 * *$ & 0.092 & 0.026 & -0.266 & -0.098 \\
\hline $\begin{array}{c}\text { Seedling } \\
\text { length }(\mathrm{cm})\end{array}$ & & & & & $0.406^{*}$ & 0.356 & $0.988 * *$ & 0.344 & 0.188 & 0.010 & 0.178 \\
\hline $\begin{array}{l}\text { Seedling fresh } \\
\text { weight (g) }\end{array}$ & & & & & & $0.612 * *$ & $0.504 * *$ & $0.665 * *$ & -0.306 & 0.015 & $0.600 * *$ \\
\hline $\begin{array}{l}\text { Seedling dry } \\
\text { weight (g) }\end{array}$ & & & & & & & $0.446^{*}$ & $0.992 * *$ & 0.053 & $0.390 *$ & $0.597 * *$ \\
\hline $\begin{array}{c}\text { Vigour Index- } \\
\text { I }\end{array}$ & & & & & & & & $0.448 *$ & 0.136 & 0.053 & 0.295 \\
\hline $\begin{array}{c}\text { Vigour Index- } \\
\text { II }\end{array}$ & & & & & & & & & -0.019 & $0.392 *$ & $0.654 * *$ \\
\hline $\begin{array}{c}100 \text { seed } \\
\text { weight }(\mathrm{g})\end{array}$ & & & & & & & & & -0.082 & -0.082 & -0.051 \\
\hline
\end{tabular}

*Significant at $5 \%$ level ** Significant at $1 \%$ level 
Positive and significant correlation was noted for seedling vigour index-I with seedling length (0.988), root length (0.952), shoot length (0.818), seedling fresh weight $(0.504)$ and seedling dry weight (0.446). Similarly, positive and significant association was also recorded for seedling vigour index-II with seedling dry weight (0.992), standard germination (0.742), seedling fresh weight (0.665), root length (0.456) and seedling vigour index-I (0.448). The 100 seed weight showed significant and negative correlation with first count $(-0.577)$ and the rest of character pairs had non-significant association. From the above results it is evident that prior estimation of standard germination, seedling dry weight and seedling vigour index-II of the seed lot any genotype could be used to predict the yield potentiality of that genotype in open field conditions and the genotype with higher values for these seed traits could be assumed to give higher pod and seed yield.

An overview of the experimental results of present investigation indicated a wide spectrum of variation in seed quality parameter among all the sixteen genotypes of vegetable pea. It can be concluded that Pea1001 had highest value for most of seed viability and seedling vigour traits. From correlation coefficients, it was evident that prior estimation of standard germination, seedling dry weight and seedling vigour index-II of the seed lot in any genotype could be used to predict the yield potentiality of that genotype in open field conditions.

In conclusion, the present investigation comprised of 16 genotypes of vegetable pea (PisumsativumL.). The seed samples of each genotype were subjected to laboratory testing in Complete Randomised Design for 100 seed weight (g), first count (\%), standard germination $(\%)$, root length $(\mathrm{cm})$, shoot length $(\mathrm{cm})$, seedling length $(\mathrm{cm})$, seedling fresh weight $(\mathrm{g})$, seedling dry weight $(\mathrm{g})$, vigour index-I and vigour index-II. It can be concluded that Pea-1001 had highest value for most of seed viability and seedling vigour traits whereas, P-89 exhibited highest pod yield per and seed yield per plant along with many other desirable traits in field conditions. From correlation coefficients, it was evident that prior estimation of standard germination, seedling dry weight and seedling vigour index-II of the seed lot in any genotype could be used to predict the yield potentiality of that genotype in open field conditions.

\section{References}

Anonymous., 2018. Area and Production of vegetable crops 2015-16 ( $2^{\text {nd }}$ Advance Estimates). www.nhb.org.in.

Choudhary, V., 2003. Vegetable, National Book Trust New Delhi, 230p.

Duke, J.A., 1981. Hand Book of Legumes of World Economic Importance. Plenum Press, New York. pp. 199-265.

Ghobary, H.M., 2010. Study of relationship between yield and some components in garden pea (Pisumsativum L.) by using correlation and path analysis.Journal of Agriculture Research36, 351-360.

Jitendra, K., Ashraf, N., Pal, K., 2010. Variability and association in garden pea (Pisumsativum L. sub sp. hortense Asch and Graebn). Progressive Agriculture 10(1), 124-131.

Koller D and Hadas A. 1982. Water relations in the germination of seeds. In: Encylopedia of Plant Physiology, Lange OL, Nobel PS, Osmond CB and Zigler $\mathrm{H}$ (eds.). SpringerVerlag, Berlin 12B: 401-431.

Kumar, V., 2007.Studies on seed quality parameter in diffrent pea (Pisumsativum L.) genotypes under hill condition. $\mathrm{M}$. Sc. Thesis submitted to G.B. Pant University of Agriculture and Technology, Pantnagar, Uttarakhand, 
India, 127p.

Maiti, R.K., Mooreno-Limon, S., 2002. Seed and seedling traits in french bean (Phasiolusvulgaris ) and its relation to abiotic stress resistance. Leg. Res. 24: 211-221.

Natrajans and Arumungam R. 2002. Selection indices in french bean (Phaseolus vulgaris L.). South Ind. Hort. 29(2):122-123.

Pal, A.K. and Singh, S. 2013.Assessment and genetic variability in garden pea (Pisum sativum L. var. hortense). 9(1): 293296.

Pant, M., 2008. Studies on morphological and seed quality parameters of vegetable pea (Pisum sativum L.). M. Sc. Thesis submitted to G.B. Pant University of Agriculture and Technology, Pantnagar, Uttarakhand, India, 43-55p.

Prasad, S., 2009.Effect of moisture stress on germination and seedling growth of vegetable pea (Pisum sativum L.). M. Sc. Thesis submitted to G.B. Pant University of Agriculture and
Technology, Pantnagar, Uttarakhand, India, 48-74p.

Raturi H C. 2013. Studies on seed priming in cucumber (CucumissativusL.). Ph. D Thesis, Department of Vegetable Science, Dr. YS Parmar University of Horticulture and Forestry, Nauni, Solan173230 (HP)-INDIA.

Shukla, P.S., Kumar, A., Prasad, S., 2009.Correlation Analysis of Seed Yield and Vigour Parameters of Vegetable Pea Varieties under Moisture Stress Condition. Trends in Bio. 2(1): 65-66.

Siddika, A.; Islam, A. K. M. A.; Rasul, M.G.; Mian, M. A. K. and Ahmed, J.U. 2013 Genetic variability in advanced generations of vegetable pea (Pisum sativum L.). Int. J. Pl. Breeding.7(2): 124-128.

Singh, J.D. and Singh, I.P. 2006.Genetic variability expected genetic advances and character association in field pea (P. sativum L.). Legume Res.21:65-67.

\section{How to cite this article:}

Abhishek Panwar, A.C. Mishra, Shivangi Negi, Sanjay Negi and Paramjeet Sajwan. 2020. Studies on Seed Quality Parameters in Different Genotypes of Vegetable Pea (Pisum sativum L.) in Mid Hills of Uttarakhand, India. Int.J.Curr.Microbiol.App.Sci. 9(01): 243-252. doi: https://doi.org/10.20546/ijcmas.2020.901.028 